\title{
Change in European Societies since the 1970s
}

Colin Crouch, Institute of Governance and Public Management, University of Warwick Business School

Revised July 2007

Paper for special $30^{\text {th }}$ anniversary issue of West European Politics 
Sociology lags considerably behind political science in its comparative research on European societies. The reason lies partly in the dependence of modern social science on quantitative data bases. These tend to be collected nationally, by national agencies, and the informal phenomena studied by much sociology are highly vulnerable to different national definitions. Some of the same problems beset political science, but there are more formal institutions that, even when they differ across countries, can at least be understood in relation to each other. The situation has begun to improve in recent years, as more data are collected by the European Commission, and as a number of large, multi-national research projects have been launched. There is now a European Sociological Association, and two major general journals (European Sociological Review and European Societies) that carry the continent's name in their titles, in addition to some specialized ones in related fields (like urban studies).

Enough material exists to enable us to talk broadly about the major changes that have taken place during these decades across western Europe, but also to some extent central and eastern Europe too. Attention will here be concentrated on those social trends that seem particularly salient for the study of politics. My starting point will be occupational structure. Although this dominant theme of classical sociology has tended to be neglected by much recent research in favour of such areas as deviance, gender and the formation of identities, working life remains fundamental to social organization and in particular to politics. In fact, the theme of gender is easily accessed through consideration of changes in occupations, and considerable attention will be devoted to it here. This leads in turn to consideration of the family, then on to other aspects of demography including immigration and cultural diversity. This relates clearly to the final theme that will be discussed: the state of religion in Europe. In the conclusions some of the political implications of these, discussed through the article, will be brought together.

\section{Occupational change}

Although the gradual decline of industrial employment in favour of various kinds of services had been predicted since the mid-20 2 th century, and 'postindustrial society' had been proclaimed since the early 1970s (Bell 1972), European politics around the time of the founding of West European Politics was still firmly rooted in industrialism. This was especially the case in the southern parts of western Europe and in France, where the move from rural agricultural employment to urban and industrial was still taking place while the shift into services was also beginning. But the generalization holds true in the north, and even in the oldest industrial nation, the United Kingdom, for the making of a population engaged in industrial work had been part of the same process that had produced the forms of the modern polity and its characteristic institutions of mass parties, rational bureaucratic public administration and, less generally, democracy. So powerful were the forces engaged in forging these historically unique forms of both working life and politics that subsequent changes leave us with the implications of 'post-'industrialism rather with a social form definable in its own terms. Alongside this, contemporary political organization reflects the decline of the politics of industrial society rather than the rise of anything new. 
The story in the eastern half of the continent is clearly different, but less so than for politics as such. Here too a central issue of previous decades had been the shaping of an industrial population, even more emphatically so than in the west, as the initial state of rural 'backwardness' was more intense, and the political determination to industrialize more all-embracing. The same drive also produced a deliberate avoidance of post-industrial tendencies, as a result of which the former state-socialist countries 'rejoined' Europe as thoroughgoing examples of industrializing societies while their western neighbours had already departed considerably from that social form.

Table 1 presents data for all countries that had produced broadly comparable statistics around the time in the mid-1970s when West European Politics was launched. Although it was then still common to consider 'services' as a single 'tertiary' sector, it is possible to examine data for three of what have become known as the four services sectors, distinguished more or less by their distance from manufacturing (Crouch 1999: ch 4). The table therefore shows, separately for men and women, employment in five sectors:

I. agriculture and mining;

II. manufacturing, public utilities and construction;

III. distribution; the movement of the products of industry and therefore still close to manufacturing activities: transport and all sales activities (including shops); postal services and telecommunications. Unfortunately, until recent years it has been common to include within these activities many of those that we now identify as sector VI (below);

IV. business services: activities that are not themselves part of the manufacturing process, but which are important to it: banks, insurance, and other financial activities; legal services; various design and consultancy activities; cleaning, security and maintenance. (The growth of this sector includes some quite illusory shifts from manufacturing to services, as manufacturing firms concentrating on their core business have sub-contracted, rather than employed directly, ancillary services.)

V. Social and community services, that is services considered to contribute to some general good going beyond the individuals who receive them (like education or health). In some cases it is not easy to identify an individual user (maintenance of the environment; police services). Because of their communal character, many of these services have historically been provided by public authorities.

VI. Personal services, considered to benefit solely the individuals who consume them: cultural and sporting entertainment, domestic cleaning, repair of domestic goods, etc. It is not possible to distinguish this sector in aggregated statistics until the late 1990s, parts of it being included in sector III.

\section{(Table 1 about here)}

Outside southern and eastern Europe, only Ireland had a primary (largely agricultural) sector employing more than $20 \%$ of the workforce at that time, though it was still above 10\% in Austria, Finland, France and Norway. Manufacturing, construction, etc was the largest sector in all countries except Greece. It employed more than $40 \%$ in Austria and West Germany, as well as three eastern European countries (Bulgaria, Czechoslovakia and Hungary), 
though not East Germany. Everywhere else, except Greece, it employed between 30 and $40 \%$. Its position within the world of male employment was even more significant. Only in some central European countries did female employment exceed a third of the total for the sector.

Distributive services and communications accounted for $20-25 \%$ of the workforce throughout almost all western Europe, but less in central Europe and Portugal. It employed relatively high proportions of women except in Greece, Ireland, the Netherlands and Portugal, while women formed a majority in Czechoslovakia and Finland. Business services were a very small sector almost everywhere. Emerging as the clear second in size to manufacturing was employment in the largely public social and community services sector. In two Scandinavian countries (Denmark and Sweden) this was already employing more than $30 \%$ of the workforce. Unlike the other sectors, this one was dominated by female employment: only in Belgium, West Germany, Greece, the Netherlands and Spain were women in a minority, and in Finland and Swden they clearly dominated the sector. The relative size of this sector, combined with the higher levels of female employment in sector II in parts of central Europe, largely determines the gender structure of the workforce at this period. In only three countries - Bulgaria, Czechoslovakia and Finland - did women constitute more than $45 \%$ of employment. In Ireland, the Netherlands, Spain they accounted for less than $30 \%$, with Greece barely above that level.

In general the mid-1970s constitute the peak of male industrial employment and the mid-20 $0^{\text {th }}$ century forms of politics associated with it. Challenging the industrial sector, as it were, is sector $\mathrm{V}$ : where the former is primarily male, concerned with the politics of production, and (in the west) largely privately owned, the latter is mainly female, mainly in public ownership and generating a politics of service provision.

The equivalent situation around 1990 is shown in Table 2. This year is both halfway through the intervening period and immediately following the collapse of the Soviet bloc. The classification base for reporting occupational structure is the same as in 1975, but data are available for more countries.

\section{(Table 2 about here)}

Agriculture and mining remain important in most central and southern European countries as well as Ireland, but are generally declining. Sector II is also declining, but remains the biggest single one in all but the Scandinavian and some north-western European countries (as well as the isolated case of Lithuania), where sector $\mathrm{V}$ is now the biggest. (In two south-eastern countries, Croatia and Greece, the distributive sector is larger than both these.) The countries with the most dominant industrial sectors are all in central Europe, with only Austria and West (but not East) Germany joining them at over 35\% of all employment. Only Norway has gone below having 25\% of employment in sector II. The distributive sector remains at between 20 and $29 \%$ for all western European countries, rather less for most central ones - particularly Lithuania and Romania. Business services remains a small sector, but exceeds $10 \%$ in the three commercially oriented economies of the Netherlands, Switzerland and the UK. Sector V accounts for more than 20\% except for Croatia, Greece, Romania and Slovakia. The Nordic countries, France, Belgium and the Netherlands have 
reached 35\% working in this sector, as has East but not West Germany. Only in Greece and Italy does this sector not have a female majority. In the economy overall women have achieved a $45 \%$ presence in two kinds of country: all the Nordics (and, almost, the UK) and the majority of central Europeans. There is a sharp difference in the profile of these two groups: in the first female employment is concentrated in a large sector $\mathrm{V}$ with a low presence in sector II; in the latter many women also work in manufacturing.

\section{(Table 3 about here)}

By the end of the period, 2005, it begins to be possible to examine sector VI in its own right. Table 3 therefore finally gives data for all six sectors. With the collapse of industrial employment in parts of central Europe, there has been some rise in the role of agriculture there; in Bulgaria and Romania this sector has again become the largest one. With the exception of Italy and Portugal, only central European countries still have more than $30 \%$ of their workforce in the industrial sector. Italy and Portugal, along with Ireland and Spain, are also the only western economies where this sector still employs more than sector $\mathrm{V}$, while Latvia is the only central European case of sector V being larger than sector II. In the Netherlands, Norway and the UK sector III is now larger than sector II. In western Europe the transition to post-industrial society may be said to be complete. The business services sector, while still small, has grown rapidly, being above $15 \%$ of employment in Ireland, Netherlands, Sweden, Switzerland and the UK. This sector has now begun to grow in central Europe, it remaining very small only in Greece and Portugal. Sector V now accounts for more than $35 \%$ of employment in Scandinavia and Belgium. It remains much lower in both central and southern Europe, giving a very clear geo-political character to this sector's position. We can for the first time inspect employment in personal services. In a mixed group of countries - south-west Europe together with Austria, Croatia, France and Ireland - it accounts for more than 5\%. Like many other services sectors, it is dominated by female employment, the sole exception being Ireland.

Overall, female employment has only passed $50 \%$ in one small country Estonia - but it is above $45 \%$ in all but nine countries, and is above $40 \%$ in all except Greece and Italy. In general the process of change in eastern and central Europe since the collapse of state socialism can be seen as moving towards the social structures of western countries. However, the state socialist economies had higher proportions of women in work than did most western European ones; in this respect they resembled the Nordic countries, the UK and USA more closely than they did the countries that make up the bulk of the pre-enlargement EU. In the majority of central European cases, 'westernization' has involved a reduction or stagnation in women's labour force participation, despite the gradual shift towards more services employment that might imply feminization. This is mainly because cuts in public spending have hit services that care for young children and the elderly, tasks which then tend to fall on women. At the same time female labour-force participation has been rising in the west, suggesting a true two-sided convergence between the different parts of Europe on this issue, rather than just a movement towards western patterns in CEE. 
Political implications of occupational change

Political sociology has long recognized the implications for political cleavages, voting patterns and party organization of the decline of manual and rise of nonmanual work. But this change is easily confused with some of the implications of sectoral change. The class structure of industrializing society, on which the political cleavages surrounding democratization were based in virtually all Europe, was itself an extension of the social order of the factory: a small owning and managing group, assisted by a junior administrative and clerical team, both separated by working environment from a manual workforce, which was itself divided by one or two broad skill demarcations. Although only a minority of the adult population anywhere ever worked in factories of this kind (an even smaller minority if account is taken of both genders), it provided the language and perceptual apparatus through which the whole population was structured, particularly for political purposes. This factory-based social structure emerged from the private practices of employers, but became embedded in government practice as much $20^{\text {th }}$ century social policy (e.g. pensions, social insurance and industrial relations institutions, qualification systems for vocational education) took on its assumptions about how industrial populations were to be classified. This further ramified their use in political organization and the structuring of cleavages.

Post-industrial occupational structure challenges this situation in two ways. The more obvious is the fact that the $19^{\text {th }}$ and $20^{\text {th }}$ century social order of the factory now accounts for an even smaller part of the workforce than it did when it was dominant. Less obviously, but perhaps more important, is the fact that there is no single equivalent paradigm sector in the new economy. To a considerable extent the office has replaced the factory as the paradigm organizational form, extending across several sectors and across the public/private divide. This produces a hierarchy of managers and professionals (the relative size of these groups varying considerably), and a large junior administrative and clerical workforce that may be larger or smaller than the professional one. The multiple gradations of this structure have so far not produced cleavages resembling those between manual workers and administrative staff that generated the politics of the $20^{\text {th }}$ century, except that there is a strong tendency for lower levels of office hierarchies to be heavily female, upper levels male, producing a gender rather than a class division. It is therefore relevant that gender has become more important than class in many political debates in recent times.

The role of the office varies in the different sectors from being the central location of organizations' activities (the business services sector, public administration) to being, as it is in the factory, ancillary (much of distribution, education, health, personal services). Also, the various services sectors have rather different internal structures. In two of them (business services and social and community services) the 'mass' workforce primarily comprises professionally qualified workers. In the distributive and private services sectors there is considerable heterogeneity, but there is often a less skilled workforce more like the factory model, though it is ambiguously definable as manual. The only one of these sectors large enough to be a potential paradigm is social and community services, but throughout Europe (and elsewhere in the advanced world) the majority provision of these services is funded by the state rather than 
through market forces. (This remains largely true even if service delivery is privatized.) It is difficult for a non- or only partially market sector to stand as the paradigm form of work organization in societies where work is primarily rooted in markets.

A further form of division within contemporary workforces concerns different contract statuses, with some persons enjoying salaried positions and some security of employment, while others are in a number of precarious positions: temporary contracts, highly insecure tenure, certain kinds of selfemployment (including 'false' self-employment), and indeed illegal employment, which plays a larger role in many economies than is usually acknowledged [Schneider]. These divisions between the relatively secure and the insecure often correspond to demographic divisions. The young and the old are both likely to concentrate in precarious jobs, an extreme case being the concentration of the young in temporary contracts in Spain. Ethnic minorities and recently arrived immigrants are likely to be heavily concentrated in insecure locations, including the black economy. In central and southern Europe women are also often in insecure jobs; in northern Europe they are more likely to be in fairly secure but part-time posts. START HERE

This emerging pattern of occupational divisions has a number of implications for politics in European countries. Should we see post-industrial society as one without major cleavages, as some have argued? Or, do cleavages exist, but are not achieving direct political expression because they are not acquiring explicit form in ways that are amenable to political mobilization? If that is the case, are they acquiring implicit expression; that is, are political issues around work being politically presented in non-occupational forms? Alternatively again, do cleavages in post-industrial societies exist, but in fields unrelated to work? These questions go well beyond the scope of the present discussion, but the issues raised here provide essential background for addressing issues of political cleavage and organization. Coverage of political sociology questions in the first 30 years of West European Politics usually drew on a Rokkanian framework of the sociology of $20^{\text {th }}$ century cleavages, but often to record their political decline (Crewe 1983; Wolinetz 1979). However, only one article, and an early one (Ersson and Lane 1981) actually discussed the decline of industrial and the rise of services employment. And there has been little that analyses the potential implications of the new structures being erected as opposed to those of the decline of the old. Some authors insisted that social structure has become less important than movements based on value orientations (Flanagan and Dalton 1984), but others provided evidence to contest this (Reiter 1993). If anything, the strongest arguments have come from those showing that, though the old cleavages might be declining, in the absence of anything clearly replacing them they retain considerable importance (Mair 1984).

These discussions have of course concentrated on west European politics. In those countries that experienced a state socialist period there was, at the level of official ideology and social policy organization, an 'inverted' class structure (Lane), whereby manual workers were represented as the key group to be served by public policy, though the structures created to give expression to this special status did not have an autonomous capacity to express the group's self-defined interests. The collapse of that system has therefore produced considerable confusion in the articulation of occupational interests, which feeds through into 
the rather unstable character of post-socialist party structures. This is not simply a result of the suppression of autonomous political organization during dictatorships: following the collapse of reactionary dictatorships in Greece, Portugal and Spain, democratic party politics rapidly acquired a familiar western European, occupation-based form (Montero 1998). It is therefore difficult to establish relationships between occupational structure and political cleavage in CEE countries, even though that structure remains less subject to the fragmentation of post-industrialism than in western European countries.

\section{Changes in gender roles}

As already indicated, one of the candidates for consideration as a new source of cleavage in post-industrial societies is gender, partly as an occupationally related category, partly sui generis. There is evidence - probably related to the different skill levels used by the sectors - that incomes are higher in business services and social and community services than in other sectors. However, even though more women work in these higher-paying sectors than men, their incomes are lower [REF]. Clearly, women are found predominantly in the lower-grade positions. Among older generations this may partly reflect the fact that male educational achievements used to be superior to female. However, virtually everywhere this has been subject to major change, and among younger generations the genders' educational performances have been reversed (Shavit etc). Another, and continuing, reason for women occupying the lower rungs in hierarchies is of course that their working careers are interrupted by childbirth and, in several countries, associated periods of either part-time work or temporary exit from the labour force [women's work refs].

This is changing as a number of factors increase the opportunities for women to enter the paid workforce, these factors operating very diversely in different European countries. First, the automation of the kitchen that took place in the west with the growth of electrical domestic appliances during the post-war decades of growing prosperity raised the productivity of domestic labour just as factory automation did to industrial labour. Second, families today have fewer children, reducing the quantity of childcare needed. Third, particularly in eastern Europe where there was far less kitchen automation, women acquired the 'double burden' [ref] of doing their housework when they finished their paid jobs for the day; sometimes their husbands may have shared these tasks, but not often. Indeed, there is also research evidence in western Europe that men have been slow to accept that their wives' engagement in paid work implies many additional domestic duties for themselves. In some countries (particularly the Netherlands and the UK) women tend to work part-time in paid employment and part-time at housework and child care. Fourth, other family members might help as a family obligation, for example grandmothers helping mothers with childcare. Finally, other people (nearly always other women) might carry out the employed woman's domestic tasks by themselves being paid to do the work. It is this last that leads to the employment-creating spiral of women's employment [Esping-Andersen].

The jobs that are created by this last process are in childcare and in other care services for the sick and the elderly that have traditionally been performed as unpaid domestic tasks by women. These services can be organized in very different ways, with major implications for how the work is reported in official 
statistics. These are often jobs in the community and social services sector, or in personal services, including food preparation, replacing domestic labour. But some of these activities are traded informally among women [Mingione ]. For example, cleaners and child-minders are usually paid informally by the women who employ them; they have no contract of employment, do not appear in any lists of persons employed, and are not registered as taxpayers. The size of this kind of female employment is therefore completely under-estimated in official statistics.

As the above Tables have shown, there remains considerable diversity among countries in their patterns of female employment. Most can be explained in the following ways. Some countries, particularly the Nordic ones but to some extent also the UK and France, developed extensive direct services within the welfare state. These countries have evinced particularly strong growth of women's employment in the social and community sector (EspingAndersen), with secondary effects as the women recruited by this expansion created further demand for female labour services as carers, etc. Rather similarly, in central and eastern Europe places of employment provided childcare facilities for working mothers, the carers being other employed women. Elsewhere in Europe, the welfare state placed a stronger emphasis on transfer payments (pensions, disability and sickness allowances, etc) than on direct service provision (for example, Germany, Italy) [Daly, Saraceno]. This restricted primary job growth among women, and therefore the multiplier process was also weaker. In these countries, primarily those in which the Roman Catholic church had a strong influence on social policy, acceptance of inter-generational family obligations remains strong, and women are likely to carry out as unpaid domestic work the activities that enable their daughters, nieces, or sisters to enter the labour force. The work is being carried out just as much as if it was being rewarded, but as with the informal economy it does not register in the job statistics.

These divergences among countries are relatively recent. U

As the above Tables have shown, in the 1970s there was less variation in women's employment between the various parts of western Europe, except for the south (Crouch 1999: ch 2; Naumann 2006). High levels of female paid work were found only in central Europe. It was from the late 1960s onwards that nearly every democratic country in western Europe started to see a major growth in welfare state expenditure. Countries differed in the size and speed of that growth, but more importantly they differed (as has been noted) in the form of the expenditure, with major implications for whether it created primarily female employment in social and community services. These differences are beginning to decline now, as female participation in formal employment in these services is growing virtually everywhere, and in western Europe very few if any political forces pursue policies that would deliberately inhibit women's employment. But past legacies remain prominent.

As already noted, the trajectory in CEE has been different. Particularly in Poland, [REFS]Catholic social policy has been able to exert political influence only since the collapse of state socialism. This has resulted in a number of policies that discourage female employment, bringing female participation down from its formerly high levels.

Returning to the west, the turn of the decade of the 1960s and 1970s also saw, in almost all these countries, a major development in women's 
consciousness, with a significant and enduring feminist movement that was to have, and continues to have, extensive implications for politics and policy. The relationship between the two factors - the growth in social services employment and feminism - is complex. Neither can be said to have 'caused' the other, but they have combined with major consequences. Although there are many examples of gender-based social movements and pressure groups, there are very few gender-based political parties. Given that political allegiances tend to be rooted in various forms of social segregation, it is difficult in societies where men and women live together for gender to articulate its conflicts in party form.

There have long been gender differences in political loyalties. For most of the $20^{\text {th }}$ century, where democracy existed women tended to ally themselves to right-of-centre parties, especially those with links to Christian churches, more than did men (Mayer and SMithy 1985). There are two good sociological reasons for this. First, left-of-centre parties usually defined themselves in relation to the concerns of manual workers in manufacturing industry, who were predominantly male. Second, in the $20^{\text {th }}$ century division of labour between the genders, women's lives were mainly centred on family, home and local community, the values of which were strongly upheld by churches. These differences were only of emphasis: some women were in paid employment, or even if they did not, they shared the life perspectives of their husbands. Also, in Catholic countries specifically Christian labour movements struggled against secular ones for the allegiance of males too. But an overall difference between men and women did exist.

These patterns have changed considerably in recent years. In most European polities gender difference in voting patterns and political allegiances have either disappeared or even been reversed [Northcutt and Flaity 1985]. The rise in female labour-force participation, and (in western Europe) the decline in both religious observation and in churches' insistence on women having primarily domestic roles, have undermined the former basis of segregation. Meanwhile, women dominate employment in social and community services, and left-of-centre parties are particularly associated with supporting public funding of these services: these factors taken together lead women to vote increasingly for these parties.

\section{Demographic trends and family changes}

Alterations in women's position have been among a number of major changes in the structure and behaviour of families. These need to be set in the context of wider changes in population patterns. As Table 4 shows, Europeans are living longer than they did a few decades ago. The trend is not so strong among men in some central and eastern European countries, where economic dislocation since the early 1990s temporarily had a negative effect. In some parts of eastern Europe and Russia, male life expectancy actually went down.

\section{(Table 4 about here)}

As death rates decline, so do birth rates (see Table 5, which shows total fertility for women of child-bearing age in a number of European countries). This generalization holds across the whole continent, and the current pattern of low 
birth rates distinguishes Europeans from most other world regions: only Japan shows similar patterns.

\section{(Table 5 about here)}

The geography of European demography contains some paradoxes. Until the decades here under review, birth rates in southern Europe were considerably higher than in northern. This was easily explicable: industrialization and growing prosperity started first in north-west Europe; and across the world and over time a strong association between modernization and declining fertility is one of the safest generalizations in the social sciences. Also, much of southern Europe is Roman Catholic, and that church had maintained an opposition to artificial contraception long after Protestant churches had abandoned it. Birth rates were also low in central and eastern Europe, which were less industrialized than much of the west, but these countries were engaged on a rapid industrialization process.

The following twin processes then seem to have reversed some of these generalizations [(Crouch 1999: ch 6?, plus others cited there)]. First, the welfarestate developments described above with relation to the Nordic countries and, to a lesser extent, France and the UK, began to make it easier for women to combine work with motherhood. Birth rates began to rise. Second, couples in southern Europe, Germany and other countries that were not pursuing employmentfriendly social care policies, who were just as keen to exercise freedom in their lifestyles as their northern counterparts, did so by reducing the number of children for whom they would have to be responsible. By the 1990s the highest birth rates in western Europe were in Scandinavia, the lowest in Italy and Spain a complete historical reversal.

Meanwhile, the upheavals in CEE countries have simply accentuated past trends to low birth rates. If these had previously been a result of the female 'double burden', since the change of regime they have resulted from the high level of economic uncertainty. Birth rates in this part of Europe are lower even than in the south.

\section{Smaller households}

In nearly all European countries, therefore, young people are forming couples later and having fewer children ([Coleman PLUS OTHERS]). This trend then joins with others to produce another change: households are becoming smaller. The other causes include a growing tendency for young adults and elderly people to live by themselves rather than in the same accommodation as other members of their families. This is the result of increased general prosperity, improving house-purchase loan systems, and (important for elderly people) both improved health in old age and improving care facilities. There is however diversity within this common trend. For example, in southern and eastern Europe birth rates are lower than in the north west; but young adults are more likely to live with their parents. Causes of these developments are clearly complex.

Decreased household size also results from a common tendency towards a decline in the number of married people ([Coleman]). This has several causes: the rise in the age of marriage discussed above; an increase in the number of couples who do not have a formal marriage; and a rise in divorce. These phenomena can 
be seen in all European countries, and in the rest of the industrialized world. There is again however considerable diversity. Divorce rates in particular are far higher in northern and eastern Europe than in the south. On the other hand, growing longevity in most parts of Europe mean that couples who stay together can expect to have more years together before widowhood.

The ageing of the population

Greater longevity combined with low birth rates produce what is often called the ageing of the population, as the average age rises. Western Europe and Japan are experiencing this in a way unparalleled elsewhere in the world or in human history. This theme primarily enters political debate in the form of a so-called pensions crisis: if the proportion of the population in work falls in relation to the proportion living on retirement pensions, there are problems for the funding of pension schemes that rely on the earnings of today's workers to fund the incomes of today's pensioners (Ferrera and Rhodes 2000). However, it is less often noticed that low birth rates also mean reduced numbers of the dependent young, and therefore reduced pressure on childcare and education budgets. A major demographic crisis of public spending occurs only if both elderly and child populations are high, with an earlier dip in birth rates having produced a small working and tax-paying population. This is not the case in contemporary Europe.

Also less noticed is the contribution that a large generation of relatively wealthy retired people make to sustaining their adult, working children at a time of increased economic insecurity [Kohli]. The prolonged period of post-war full employment, accompanied by major improvements in state retirement pension provision immediately after World War II and then again after the 1970s have meant that, for the generations that entered the workforce during that era, old age has not been a time of poverty [Albertini]. This has been a remarkable change from previous generations. In most western European countries this was also a period of growth in home ownership. The majority of today's elderly among ordinary working people have considerably more financial resources than their predecessors. The role of this stabilizing force in a contemporary economy and labour market characterized by uncertainty is a subject that would repay research.

This factor is likely to prevent the emergence of a generational cleavage. Such a cleavage is sometimes predicted because of the ostensible conflict between those enjoying good pensions and those who come after them, funding those pensions from their taxes while probably not being able to look forward to having them themselves. In addition, younger people are aware that if their parents do not have sound pensions, the burden of their care will probably fall back on to them. They are therefore more likely to respond by insisting on the maintenance of generous pensions and their continuation until their own generation, rather than welcome tax cuts that could follow a reduction in pension cover. This logic probably explains why campaigns against cuts in pensions for public employees in France have attracted sympathy from parts of the public who do not themselves benefit from them (Bonoli 1997).

Immigration and cultural pluralism 
Extensive immigration into western Europe from less prosperous parts of the world has been a long-standing phenomenon. In recent years this has extended to the Nordic countries, Italy and Spain. The latter, for so long countries of emigration, have found themselves attractive to people in northern Africa, geographically close. Following the collapse of the Soviet bloc, there are now also major movements of people from eastern and central Europe towards the west.

Unlike the migrations of the 1960s, which took place when there were labour shortages in western Europe, these new movements are taking place at a time when there is high unemployment in much of the latter region. Meanwhile, half a century of immigration into some parts of western Europe has produced second and third generations of people descended from immigrants, but born and brought up in Europe, sometimes intermarrying and forming new families with people from the host society. Although such cultural mixing has always been a characteristic of many European countries, this longer European history has also been marked by major episodes of intolerance, hatred, and bloodshed. Elements of this continue to dog the creation of multicultural societies today, as dominant majorities and immigrant or post-immigrant minorities try to come to terms with each other. These difficulties sometimes create major political issues, and anti-immigrant parties, or factions within existing parties, have become among the major innovations on the party-political scene (Messina 1990; West European Politics 1994).

In some cases these new cultural issues affect societies where tension still exists from older patterns of difficult relations between majorities and older settled minorities. Relations between Catholics and Protestants in Northern Ireland and between Basques and Spaniards in northern Spain have been among the most persistent in western Europe. It is however in eastern and central Europe that this kind of tension remains strongest. During the 1990s the former state of Yugoslavia collapsed under the weight of extreme violence bordering on attempted genocide among its diverse cultural and religious (Catholic, Orthodox, and Muslim) populations. These have now formed separate states more or less following these cultural contours, with continuing tensions. Elsewhere such issues as the place of Hungarians in Romania, of Turks in Bulgaria, of Russians in the Baltic states, of Gypsies in many countries, continue to produce means of political mobilization, sources of discrimination and occasional outbursts of violence.

\section{The decline of European religion}

While there is debate about what indicators should be used, there is little doubt that religion is an institution in major decline throughout Europe - except among some of the immigrant communities mentioned above. This trend became manifest first in a decline in attendance at religious services by people who continued to regard themselves as members of churches or other religious organizations, or at least as believers. More recently however there has also been a decline even in affirmations of a belief in God [REF]. Further, the European situation contrasts very considerably with that in the USA, where religious belief, church attendance, and the political power of religious organizations have been growing very strongly indeed. Europe, along with Japan, stands out as a world region of religious decline at a time when the institution is rising in prominence in the USA, the extensive Islamic world, and some other areas. 
There are however important differences in the patterns. In the UK, and more recently the Netherlands, religious observance of all kinds has sunk to very low levels. In the Nordic countries, while regular church attendance is the lowest in the world, large majorities of the population are confirmed into the church and opt to pay a voluntary religious tax to fund their churches. In some other countries, including Italy, Ireland, and Poland, church attendance remained high until the past decade or so [REFERENCE].

The decline in Poland is particularly striking, as the Catholic Church had been a major source of Polish national identity during the years of Soviet domination, and had played a major part in undermining the state socialist regime. It had been widely expected that there would be a major Christian renaissance, not only in Poland, but throughout central and eastern Europe, where churches (variously Orthodox, Catholic, and Lutheran) had remained a stable symbol of popular identity during years of disorientation. At the level of political influence this has often been the case, religious leaders acquiring a dominant role in social policy in particular. However, this trend has contradicted that in popular behaviour. In fact, in Poland and elsewhere the Christian churches have declined rapidly in central and eastern Europe following the fall of communism, as those countries have joined a general European trend.

In general the history of religion in modern Europe has followed a clear pattern (Martin). Where the dominant church made strong demands on the loyalty of populations and exercised a major political influence, people became divided between supporters of that church role and outright opponents of it. This was largely the case with the Catholic Church, and also of Calvinist Protestant churches, which tend to flourish in embattled situations where Protestants face strong Catholic, and/or secular or other opposition (the Netherlands, Scotland, Northern Ireland, to some extent Switzerland; outside Europe in South Africa). National churches that became content to express the common life of a nation state without making political claims other than securing their own quiet position in that life tended to attract neither the support nor the hostility to which the Catholic Church was liable. Declining numbers took an interest in their activities, but few bothered to challenge their claim to a quiet place in national life. This has been the fate of the Church of England in England and the Lutheran churches in the Nordic countries. In a somewhat different way, it has also been the pattern in Eastern Europe, where the Orthodox Church takes the form of a number of national churches.

Where religions of various kinds express the identity of people against, or at least separately from, an alien political power, that religion can attract powerful loyalties as in the dominant Catholic case (ibid). Here however this is without the antagonism attracted by a church's exercise of power over people, as this is experienced as an alternative to a more remote political authority. What such religions have to fear is the passing into insignificance of the identity that they express. There are many, varied examples of this phenomenon. The Catholic Church has been in this position where a Catholic population has been dominated by non-Catholics - as in Ireland (long dominated by the British) and Poland (dominated, among others, by the Russians). Those countries did not experience strong secularist movements. Long after Greek independence from Turkey, the Greek Orthodox Church still plays a similar role for Greeks. 
Religions today often play this powerful cultural identity role for ethnic minorities, and an earlier expression of internal local cultural diversity is replacing that of regionalism in many European societies today. Jews have long been an example of this. Following the more recent waves of immigration, Islam, Hinduism, Buddhism, the distinctive forms of Christianity found in Africa and the Caribbean, and some others, have provided valuable identities among immigrant groups and their descendants, becoming important constituents of the cultural pluralism mentioned above. Typically, therefore, ethnic minorities have far higher patterns of religious observance than native populations.

\section{Conclusion}

The societies of central and eastern Europe have joined the general history of capitalist economic development when it is at a moment of considerable change. The late $19^{\text {th }}$ and $20^{\text {th }}$ century economy built around male workers in manufacturing industry is giving way to one based around various services. This is a particularly strong challenge for the former state socialist countries, as services played a particularly small role in employment in their economies. Meanwhile, both parts of Europe have left behind them the forms of economic organisation that provided basic security to their working populations in the decades after World War II: Keynesian demand management in the west, a centrally planned economy in the west. Both now face the more turbulent global market economy. The struggle among populations for security in this context partly takes the form of the protective role of the welfare state, stronger in northern Europe than anywhere else, and partly that of different levels of security provided by different forms of work contract and associated labour rights. To some extent these areas become fields of distributional and therefore political conflict, as different demographic and occupational categories achieve different levels of social rights.

For most of the $19^{\text {th }}$ and $20^{\text {th }}$ centuries the politics of most European countries was shaped by two major conflictual forces. The first was struggle between religions, or between religion and secularism. The second was class struggle, first between landed aristocracy and the rising commercial and industrial bourgeoisie, and then between the latter and the rising manual working class rooted in manufacturing and mining industries. The party systems of Europe still bear the imprint of these struggles more than of any other. But they all refer to events of the past. This is not because there are no struggles over religion and class in $21^{\text {st }}$ century society, but they concern different issues. First, relations between ethnic and religious minorities and their host societies take the form of potential clashes between cultures rather than religious conflict in the strict sense. Second, the class conflicts around which party politics is organized still concern the role of the industrial working class.

The political agenda has responded to change. Issues of globalization and the transition of employment forms from those designed for large-scale manufacturing to those designed around the new services sector are important everywhere, from the prosperous economies of western Europe to those in the centre and the east entering the scene of these new issues while they are still embroiled in the transition from state socialist to capitalist economies. Changes in the role of women, and challenges for the welfare state created by both those changes and the wider shifts in employment patterns are similarly important. 
Immigration is also a political issue. In this last case both racist or populist parties or fractions of parties representing ethnic minorities have certainly entered the political stage. But otherwise party structures and rhetoric have remained largely static. The new issues of the transition to the services economy, and the new social groups forged by them, have so far found little autonomous expression. In the west this may be reflected in growing popular apathy towards politics and an apparent growing gulf between political classes and the mass of the population. In central and eastern Europe we see a difficulty in establishing stable party structures that might express people's conflicts and aspirations, and instead a rapidly changing series of personal cliques formed around individual political leaders.

\section{References}

Bell 1972

Crouch 1999

[Schneider] 